\title{
PENDIDIKAN DALAM PERSPEKTIF POLITIK KEBANGSAAN
}

Kabibulloh

Program Studi Pendidikan Agama Islam

\section{PENDAHULUAN}

Kondisi bangsa Indonesia saat ini cukup memprihatinkan, terpuruk disegala sektor, ketidakstabilan polik dan ekonomi, dekadensi moral, padahal sudah lebih dari 65 tahun Indonesia merdeka sebagai Negara yang bebas dan berdaulat untuk menentukan arah bangsa. Faktor keterpurukan yang terjadi di Indonesia menurut Soedijarto karena mengabaikan pendidikan sebagaimana digariskan oleh Bung Karno yaitu pendidikan sebagai wahana untuk menunjang transformasi budaya menuju tegaknya Negara kebangsaan yang berperadaban tinggi, (Soedijarto, 2008).

Konsep ideal pendidikan yang dicita-citakan untuk mencapai masyarakat Indonesia yang sejahtera yang mempunyai kepribadian luhur dan berperadaban tinggi. Untuk itu perlu menerjemahkan konsep tersebut menjadi lebih operasional dan realistik sesuai dengan kondisi Bangsa Negara Indonesia supaya dapat dilaksanakan oleh para pelaku pendidikan. Sehingga tidak lagi menjadi cita-cita yang mulia yang hanya ada dalam angan-angan/utopis, tetapi bisa membumi di bumi Nusantara Indonesia.

Upaya untuk mencapai masyarakat yang sejahtera dan berperadaban, bisa dibangun melalui pendidikan. Tersedianya pendidikan yang berkualitas dan bermutu menjadi sangat mutlak diperlukan untuk dapat menciptakan manusia yang sempurna (insan kamil) yang dapat membangun bangsa Indonesia lebih maju dan berperadaban dengan memanfaatkan ilmu pengetahuan dan teknologi. Rancangan tentang konsep pendidikan Indonesia tertuang dalam ketetapan Undang-Undang Sistem Pendidikan Nasional yang mengacu pada UUD 1945, dan masih bisa diterjemahkan lagi menjadi lebih operasional kedalam bebrapa bentuk kebijakan supaya bisa dilaksanakan secara efektif dan efisien sesuai dengan tujuan bangsa Indonesia. Selain itu upaya untuk pemerataan pembangunan bangsa Indonesia dilakukan dengan ketetapan tentang otonomi daerah, dengan menetapkan Undang-Undang Otonomi Daerah. 


\section{FUNGSI SISTEM PENDIDIKAN NASIONAL INDONESIA}

Begitu pentingnya pendidikan bagi suatu bangsa sebagai proses transformasi dan pengembangan potensi untuk meningkatkan kualitas sumber daya manusia, maka para founding father dalam pembukaan UUD 1945 pada alinea keempat mencantumkan kalimat "mencerdasakan kehidupan bangsa" sebagai salah satu tujuan bernegara bagi Bangsa Indonesia. Kemudian keinginan untuk mencerdaskan Bangsa Indonesia melalui pendidikan diperjelas dalam pasal 31 UUD 1945 ayat 1) Setiap warga Negara berhak mendapatkan pengajaran, dan ayat 2) Pemerintah mengusahakan dan menyelengggarakan satu sistem pengajaran nasional, yang diatur dengan undang-undang, yang kemudian diamandemen dengan penegasan ayat 2) Setiap warga Negara wajib mengikuti pendidikan dasar dan pemerintah wajib membiayainya. Hal ini menunjukkan bahwa pendidikan merupakan komponen yang sangat penting untuk membangun bangsa yang cerdas dan bermartabat. Untuk mencapai itu merupakan suatu kemutlakan jika pemerintah harus menyediakan pendidikan bermutu dan demokratis bagi seluruh warganya.

Cita-cita yang mulia dari para pendiri bangsa sebagaimana tercantum dalam pembukaan UUD 1945, yaitu mencerdaskan kehidupan bangsa dapat dipahami bahwa adanya keinginan yang kuat untuk membangun bangsa Indonesia yang sangat beragam dari sabang sampai merauke menjadi bangsa yang maju dan berperadaban yang masyarakatnya cerdas. Masyarakat yang cerdas hanya bisa dicapai melalui pendidikan yang berfungsi sebagai transformasi kebudayaan, yaitu pembudayaan kemampuan, nilai dan sikap menuju masyarakat modern dengan penguasaan IPTEK dalam konteks saat ini. Maka untuk tujuan membangun Negara bnagsa dalam pengertian satu kesatuan sistem sosial-budaya (politik, ekonomi, sosial dan budaya) ditetapkanlah pasal 31 ayat (2) UUD 1945 dimana pemerintah berkewajiban mengusahakan dan menyelenggarakan satu sistem pengajaran nasional, yang diatur dengan undang- undang. Berdasarkan hal tersebut apabila seluruh warga Negara bangsa menghayati proses pembelajaran untuk meghayati nilai- nilai sosial budaya yang bersifat nasional yang disepakati bersama maka bangunan Negara bangsa dapat didukung, (Soedijarto, 2000). 
Dengan demikian cita-cita mencerdaskan kehidupan bangsa sebagai konsep pendidikan perlu diterjemahkan secara operasional untuk dapat menjadikan pendidikan sebagai proses transformasi budaya (pembudayaan kemampuan, sikap dan nilai serta modern). Melalui sistem pendidikan nasional yang diwujudkan dalam Undang-undang, tugas para pengambil kebijakan dan pakar untuk mewujudkan hal tersebut.

Upaya untuk mengejewantahkan konsep pendidikan menjadi konsep yang lebih operasional diwujudkan memalui Undang-undang Sistem Pendidikan Nasional mulai dari UU No. 4 Tahun 1950 sampai UU No. 20 Tahun 2003. Walaupun terkadang konsep sistem pendidikan nasional masih perlu diterjemahkan lagi menjadi lebih operasional untuk mencapai tujuan pendidikan yang diinginkan. Sehingga perlu dicermati sistem pendidikan nasional Indonesia.

Tujuan pendidikan nasional telah dirumuskan dalam beberapa UU Pendidikan Nasional, yaitu: UU No. 4 Tahun 1950, Jo UU No. 12 Tahun 1954, mencitakan manusia terdidik Indonedia sebagai “ manusia susila yang cakap dan demokratis serta bertanggung jawab". Kemudian, UU No. 2 Tahun 1989, mencitakan wujud manusia Indonesia terdidik sebagai "manusia yang beriman dan bertaqwa, sehat jasmani dan rohani, memiliki pengetahuan dan ketrampilan, berkepribadian yang mantap dan mandiri serta mempunyai rasa tanggung jawab kemasyarakatan dan kebangsaan”. Dan, UU No. 20 Tahun 2003, mencitakan “ manusia yang beriman dan bertaqwa kepada Tuhan Yang Maha Esa, berakhlak mulia, sehat, berilmu, cakap, kreatif, mandiri, dan menjadi warga negara yang demokratis serta bertanggung jawab" pada dasarnya tujuan pendidikan nasional yang pernah dirumuskan dalam UU Pendidikan Nasional Kesemuanya mencitakan sosok manusia yang ideal (insan kamil).

Untuk mencapai tujuan pendidikan sebagaimana yang telah dicita-citakan Bangsa Indonesia, maka pendidikan nasional diharapkan mampu melahirkan manusia Indonesia yang:

1. Religius dan bermoral;

2. Yang menguasai ilmu pengetahuan dan ketrampilan;

3. Yang sehat jasmani dan rohani; dan

4. Yang berkepribadian dan bertanggung jawab, (Soedijarto, 2008). 
Era globalisasi yang ditandai dengan modernitas dan IPTEK mencitakan masyarakat yang berbudaya (positif), maka dari itu Bangsa Indonesia akan bisa bertahan sebagai Negara yang merdeka dan bermartabat bila memiliki sumberdaya manusia yang dapat mendukung:

1. Sistem politik demokrasi yang stabil berdasarkan pancasila;

2. Sistem ekonomi nasional yang mantap infrastruktur fisiknya, infrastruktur teknologinya, infrastruktur manusianya, berkembang wirausahanya, dan tumbuh pengusaha kecilnya;

3. Sistem pengembangan iptek yang tangguh;

4. Majunya kebudayaan dalam berbagai segi, baik kesenian, kesusastraan, maupun dimensi kognitif dan normative dari kebudayaan nasional; dan

5. Mantapnya etika ekonominya, (Soedijarto, 2008).

Sehingga untuk menjawab tantangan globalisasi sebagai masyarakat modern., manusia terdidik Indonesia harus menguasai kemampuan, nilai dan sikap, yang terdiri dari:

1. Memiliki kemampuan, nilai, dan sikap yang memungkinkan berpartisipasi secara aktif dan cerdas dalam proses politik;

2. Memiliki kemampuan, etos kerja, dan disiplin kerja yang memungkinkan aktif dan produktif berpartisipasi dalam berbagai kegiatan ekonomi;

3. Memiliki kemampuan dan sikap ilmiah untuk dapat mengembangkan ilmu pengetahuan dan teknologi melalui kemampuan penelitian dan pengembangan; dan

4. Memiliki kepribadian yang mantap, berkarakter dan bermoral, serta berakhlak mulia, Soedijarto, 2008).

Hanya melalui pendidikan yang berkualitas dan bermutu kompetensi sumberdaya manusia yang diharapkan dapat menjawab tantangan globalisasi dan modernisasi. Salah satu yang perlu diperhatikan adalah efektifitas, ketepatan dan cakupan materi yang diajarkan kepada peserta didik, kita bisa lihat materi untuk pendidikan dasar dalam undang-undang pendidikan nasional:

1. UU No. 2 Tahun 1989 (pendidikan dasar) a. Pendidikan Pancasila.

b. Pendidikan Agama.

c. Pendidikan Kewarganegaraan. 
d. Bahasa Indonesia.

e. Membaca dan Menulis.

f. Matematika, termasuk berhitung.

g. Pengantar sains dan teknologi.

h. Ilmu bumi.

i. Sejarah nasional dan sejarah umum.

2. UU No. 20 Tahun 2003 (sampai SM) a. Pendidikan Agama.

b. Pendidikan Kewarganegaraan.

c. Bahasa.

d. Matematika.

e. Ilmu Pengetahuan Alam.

f. Ilmu Pengetahuan Sosial.

g. Seni, Budaya, dan Olah Raga, serta

h. Ketrampilan, Kesenian, dan Muatan Lokal.

i. Kerajinan Tangan dan Kesenian.

j. Pendidikan Jasmani dan Kesehatan.

k. Menggambar.

1. Bahasa Inggris.

Menurut Phenix sebagaimana dikutip oleh Soedijarto terdapat empat prinsip dasar dalam memilih media pembelajaran, yaitu:

1. Bahan Pelajaran harus diambil dari disciplined of inquiry;

2. Bahan pelajaran harus dipilih dari konsep-konsep utama suatu disiplin yang mewakili hakikat disiplin tersebut;

3. Bahan pelajaran mengutamakan method of inquiry; dan

4. Bahan pelajaran harus dapat mendorong peserta didik berpikir secara imajinatif, (Soedijarto, 2008).

Menurut Soedijarto UU No. 2 Tahun 1989 masih relevan dalam upaya mencerdaskan kehidupannya bangsa dan memajukan kebudayaan nasional. Masalahnya adalah fungsi dan tujuan pendidikan mulai SD samapi Perguruan tinggi tidak diupayakan terwujud, dimana pendidkan mulai dari SD sampai perguruan tinggi masih merupakan proses penyajian informasi sebagaimana proses pembelajaran 
sebelum UU No. 2 Tahun 1989. Maka dibutuhkan proses pembelajaran yang bermakna pebudayaan,(Soedijarto, 2008). Pada prinsipnya penerjemahan konsep pendidikan menjadi operasional dari konsep pendidikan yang dibangun dalam UUD 1945 kedalam konsep-konsep pendidikan nasional masih sesuai dengan tujuan dari pendidiikan nasional. Masalahnya adalah belum adanya keseriusan yang sungguhsungguh secara kolektif dari para pengambil kebijakan dan pelaku dalam pendidikan nasional untuk melaksanakan konsep dalam undang-undang sistem pendidikan nasional sebagai wujud operasionalnya.

Jika melihat kondisi pendidikan yang terjadi sampai saat ini,maka pendidikan sebagai transformasi budaya dalam membentuk karakter dan mental generasi muda, tidak bisa mungkin tercapai dengan kondisi sekolah yang berjubel dengan guru yang kurang professional, dan proses pembelajaran yang hanya dengan mencatat, menghafal dan mengingat kembali, (Soedijarto, 2008). Supaya pembelajar sampai pada "joy of discovery" kita bisa mengacu pada ketentuan dari UNESCO yang memperkenalkan empat pilar belajar yaitu: Learning to know, lerning to do, learning to be, dan learning to live together. Dengan pelaksanaan pendidikan yang mencapai empat pilar dalam belajar tersebut, pendidikan akan lebih bermakna dan berguna bagi tercapainya fungsi pendidikan sebagai pusat pembudayaan kemampuan, nilai, dan sikap serta modern sebagaimana dicita-citakan masyarakat modern. kemudian dalam mengembangkan kepribadian anak didik sekolah mempunyai peran yang antara lain:

1. Mengajarkan anak bergaul baik sesama anak didik, dengan guru maupun dengan karyawan (bukan guru).

2. Mengajarkan anak didik mentaati peraturan-peraturan sekolah.

3. Mempersiapkan anak didik untuk menjadi anggota masyarakat yang berguna bagi agama, bangsa dan Negara, (Hasbullah, 2009).

Untuk mencapai tujuan pendidikan secara optimal dengan menanmkan kemampuan, nilai dan sikan sebagai bentuk pembudayaan, diperlukan system evaluasi belajar yang dapat merangsang dan menantang peserta didik untuk terus mengembangkan potensi dirinya. Berkaitan dengan evaluasi belajar, tidak mesti harus dengan Evaluasi Hasil Belajar seperti UN. Karena UN hanya mengukur segi kognitif (penguasaan pengetahuan yang telah dihafal). Ketetapan tentang UN tidak berdampak 
pada tercapainya tujuan nasional sebagaimana UU No. 20 Tahun 2003, yakni mendorong peserta didik aktif mengembangkan potensi dirinya. Menurut penelitian Benjamin Bloom sebagaimana dikutip oleh Soedijarto, bahwa tingkah laku peserta didik akan dipengaruhi oleh perkiraan peserta didik tentang apa yang akan diujikan, (Soedijarto, 2008).

UN sifatnya hanya menguji dari penguasaan pengetahuan yang telah dihafal, maka dengan sendirinya peserta didik hanya akan belajar materi yang akan diujikan. Peserta didik akan belajar secara borongan untuk mencapai tujuan yang akan dicapai, disampaing juga pengaruh dari para pengambil kebijakan supaya peserta didik bisa lulus UN seperti kepala sekolah, kepala dinas, dan pihak-pihak yang terkait dengan demikian evaluasi belajar tidak harus hanya dengan UN untuk tingkat SMP dan SMA. Apalagi untuk tingkat SD, sesuai dengan pasal 31 ayat (2) UUD 1945 dan UU No. 20 Tahun 2003, dimana sekolah dasar (SD) bukanlah lembaga terminal, melainkan bagian dari pendidikan dasar. Jika wajib belajar 9 tahun berarti sampai SMP, ukuran orang mengikuti wajib belajar adalah berdasarkan lamanya belajar, jadi tidak ada lulusan SD yang ada adalah naik kelas dari kelas 6 naik ke kelas 7 (SMP kelas satu).

Supaya peserta didik dalam setiap jenjang pendidikan dapat secara terus menerus dan intensif melakukan proses pembelajaran yang bermakna bagi tercapainya berbagai tujuan pendidikan, perlu dikembangkan dan dilaksanakan evaluasi secara komprehensif, terus- menerus dan objektif. Evaluasi yang demikian hanya dapat dilakukan oleh guru professional yang mampu merencanakan, mengelola, memotivasi, dan menilai proses pembelajaran yang berlangsung setiap hari, (Soedijarto, 2008).

Guru merupakan faktor utama dalam pendidikan untuk menanamkan nilai dan kepribadian serta pengetahuan, bahkan Mantan Presiden Soeharto sebagaiamana dikutip oleh Abu Ahmadi, pada peringatan Hari Pendidikan Nasional pernah berpesan bahwa dalam menanamkan nilai-nilai pancasila pada peserta didik, pertama- tama gurulah yang harus pertama-tama mempancasilakan dirinya, karena hanya guru pancasila yang dapat menyebarkan pancasila, (Abu Ahmadi\&Nur Uhbiyati, 2003). Begitu juga dalam pendidikan sebagai pusat pembudayaan kemampuan, nilai dan 
sikap, hanya guru yang berkualitas dan professional yang dapat mengemban misi tersebut, oleh sebab itu seorang guru/pendidiik harus benar-benar menguasai:

1. Bidang studi yang menjadi tanggung jawabnya;

2. Karakteristik peserta didik/mahasiswa/peserta latihan;

3. Berbagai model pembelajaran;

4. Teknologi pendidikan; dan

5. Sistem evaluasi.

Dalam mengembangkan program pembelajaran, penanggung jawab suatu mata pelajaran dalam hal ini guru yang professional harus dapat melakukan beberapa hal sebagai bentuk kompetensi, yaitu harus dapat:

1. Merancang model pembelajaran yang relevan dengan topik dan tujuan kurikulum;

2. Memilih bahan belajar, baik buku, jurnal, atau laporan yang relevan;

3. Memilih media belajar yang sesuai;

4. Merancang bentuk interaksi belajar antar peserta dengan peserta dan peserta dengan widyaswara; dan

5. Merancang program evaluasi yang terus-menerus yang dapat meliputi penugasan melakukan observasi dan menyusun laporan hasil observasi, penugasan membaca buku dan hasilnya didiskusikan, dan berbagai penugasan lainnya yang relevan, yang kesemuanya dinilai secara proposional untuk mendapat nilai akhir.

Jika dilihat dalam ketentuan UU Sistem Pendidikan Nasional,

1. Kompetensi pedagogik;

2. Kompetensi kepribadian;

3. Kompetensi social; dan

4. Kompetensi professional, (UU No. 14 Tahun 2005).

Perhatian terhadap terpenuhinya guru professional telah dilakukan dengan memberikan batasan terhadap kualifikasi guru professional. UU No. 14 Tahun 2005 Pasal 8, tentang karakteristik seorang guru professional dinyatakan: "guru wajib memiliki kualifikasi akademik, kompetensi, sertifikat pendidikan, sehat jasmani dan rohani, serta memiliki kemampuan mewujudkan tujuan pendidikan nasional", (UU No. 14 Tahun 2008), Dari ketentuan pasal 8 UU No. 14 Tahun 2005, pada hakekatnya merupakan suatu satu kesatuan dimana kualifikasi akademik merupakan kondisi bagi 
dapat dikuasainya kompetensi professional, sedangkan sertifikat pendidikan adalah pernyataan resmi tentang telah dikuasainya kualifikasi akademik dan kompetensi tersebut, dan ketiganya hanya akan dipenuhi bila seorang calon guru sehat jasmani dan rohaninya, Soedijarto, 2008). Oleh sebab itu seorang guru harus menguasai beberap kompetensi, kompetensi yang harus dikuasai oleh guru adalah :

Sebagai pendidik yang professional yang menetukan kualitas proses pembelajaran, maka seorang guru harus melakukan:

1. Perencanaan program pembelajaran;

2. Mengelola proses pembelajaran;

3. Menilai proses dan hasil pembelajaran;

4. Mendiagnosis masalah yang dihadapi peserta didik; dan

5. Terus memperbaiki program pembelajaran selanjutnya, Soedijarto, 2008).

Guru professional tidak begitu saja akan bisa terbentuk dengan sendirinya, tetapi memerlukan proses untuk dapat membentuk guru yang professional baik melalui penguasaan kompetensi maupun latihan. Kemudian, indikator kemampuan professional diatas dapat dijadikan acuan dalam menilai untuk menentukan guru professional. Dan, kewenangan untuk menentukan guru professional dengan membera sertifikat adalah Universitas yang memiliki LPTK, sebagaimana ketentuan pasal 11 ayat (2) UU NO. 14 Tahun 2005 tentang Guru dan Dosen, "Sertifikasi pendidik diselenggarakan oleh perguruan tinggi yang memiliki program pengadaan tenaga kependidikan yang terakreditasi", (UU No. 14 Tahun 2005).

Untuk menjawab tantangan pendidikan di era globalisasi dengan masyarakat yang heterogen dengan perkembangan ilmu pengetahuan dan teknologi sebagai sumber objek belajar, maka diperlukan upaya peningkatan profesionalisme guru untuk dapat melaksanakan pendidikan yang berkualitas khususnya dalam pelaksanaan KBK. Karena kondisi tingkat kemampuan guru masih beragam, dengan demikian diperlukan pengadaan guru dan tenaga kependidikan secara terencana untuk meningkatkan profesionalitas guru, melakukan seleksi terhadap calon guru melalui pemilihan mahasiswa untuk dipersiapkan menjadi guru yang professional. Perlu merancang kurikulum yang dipersiapkan bagi calon guru, menyiapkan calon pengajar yang professional bagi calon guru, model pembelajaran yang tetap, pemilihan sistem 
evaluasi yang bisa diterapkan secara efektif, diperlukan juga bagi calon guru untuk melakukan praktek pengajaran, implikasinya adalah diperlukan pembiayaan yang cukup besar untuk dapat menyediakan guru yang professional termasuk kesejahteraan guru sebagai konsekuensi dari profesionalitas.

Dengan demikian konsep yang dibangun dalam ketentuan UUD 1945 Pasal 31 dan UU Sisdiknas No. 20 tahun 2003 pada prinsipnya sudah bisa dijadikan acuan dalam membangun bangsa Indonesia menjadi lebih maju melalui pendidikan yang berfungsi sebagai proses pembudayaan atau transfer kebudayaan, tidak hanya sekedar berfungsi sebagai transfer pengetahuan (transfer of knowledge). Sehingga jika rancangan tersebut dapat dilaksanakn secara konsekuen dan sungguh- sungguh oleh semua pihak yang terkait, mutu pendidikan kita dapat ditingkatkan.

\section{IMPLIKASI OTONOMI DAERAH DALAM PENDIDIKAN}

\section{Alasan dan Beberapa Contoh Desentralisasi Pendidikan}

Pelaksanaan desentrasliasi di banyak Negara, termasuk di Indonesia, didasari sejumlah alasan dan menampilkan contoh yang berbeda-beda, di antaranya berikut ini.

\section{a. Menghindari beban pemerintah}

Sistem pemerintahan yang sentralistik mengakibatkan beban menjadi berat ke atas, yaitu pemerintah pusat. Desentralisasi antara lain dimaksudkan untuk mendistribusikan beban tersebut ke daerah-daerah sehingga beban pemerintah pusat berkurang dan sebagai penggantinya, pemerintah daerah beserta masyarakat ikut menanggung beban tersebut. Namun tanpa adanya dukungan politik dan kesediaan daerah untuk menanggung beban baru tersebut, desentralisasi akan menemui kegagalan. Hal seperti ini pernah terjadi di Argentina pada pertengahan tahun 1970an, ketika pemerintah pusat mendesentralisasikan banyak urusan pemerintahan ke daerah- daerah, sekaligus untuk memberdayakan partisipasi masyarakat. Namun daerah menolak tanggung jawab finansial, sehingga selama satu dekade penyelenggaraan pemerintahan di Negara itu mengalami kekacauan.

\section{b. Penyantunan Demokrasi}

Misalnya, India dengan penduduk lebih dari 900 juta, terkenal sebagai Negara yang memiliki tradisi demokrasi yang kuat dengan diversitas budaya yang luas. Negara ini memiliki 1.600 dialek dan terbagi ke dalam 25 Negara Bagian. 
Berdasarkan undang- undang, pendidikan terbuka bagi siapa pun. Ada upaya pemerintah secara top-down untuk mengembangkan desentralisasi pendidikan, sehingga pendidikan yang terbaik sekalipun dapat diakses oleh orang dari kelompok manapun. Pendidikan juga menjadi sarana untuk mendukung pengembangan demokrasi.

\section{c. Laissez faire di bawah kekuasaan yang otoriter}

Pada tahun 1970-an, Chile berada dibawah pemerintah militer. Rezim ini menghancurkan Negara. Guru dianggap sebagai musuh pembangunan dan kehilangan martabatnya. Serikat pekerja dilarang. Segalanya sangat sentralistik. Sebanyak $43 \%$ keluarga pendapatan terendah dapat mengakes pendidikan. Pada 1980, pemerintah militer memberi peluang kepada seorang ekonom neoliberal lulusan Universitas Chicago untuk mengadakan berbagai desentralisasi dan privatisasi. Upaya tersebut tidak berhasil karena tradisi otoriter masih berlangsung, sementara pemerintah daerah tidak berdaya. Maka yang kemudian terjadi adalah tumbuhnya kekacauan dan laissez faire dengan pola perubahan yang tidak terkendali.

\section{d. Desentralisasi dalam iklim yang korup dan sentralistik}

Sampai pada tahun 1978, pemerintahan Meksiko sangat sentralistik. Di Negara bagian yang miskin, kurang dari $20 \%$ anak yang memperoleh pendidikan. Mulai tahun 1978, diadakan desentralisasi dalam bentuk dekonsentrasi layanan pada 31 negara bagian. Delegasi merentang dari penyusunan anggaran hingga pengelolaan sekolah dan penjabaran kurikulum, sementara pemerintah pusat hanya menyusun kurikulum intinya. Desentralisasi ini memacu pertambahan jumlah siswa, terutama di daerah pedesaan yang miskin.

\section{e. Desentralisasi karena besarnya cakupan wilayah}

Pada tahun 1990, Brasil mulai melaksanakan wajib belajar 8 tahun, tetapi tidak terjadi perubahan yang signifikan dalam kinerja pendidikannya. Mutu pendidikan tetap rendah, biaya pendidikan kurang, pendidikan guru kurang bermutu, manajemen pendidikan kaku, putus sekolah tinggi, dan hanya 40\% siswa berhasil menyelesaikan pendidikan hingga kelas 8. Kemudian, kebijakan baru menetapkan bahwa pengelolaan sekolah diserahkan kepada masyarakat setempat. Setiap sekolah diminta membentuk Dewan Sekolah yang terdiri atas wakil guru, kepala sekolah, 
wakil orang tua, dan wakil siswa (yang berusia di atas 16 tahun). Pemerintah memberikan bantuan keuangan berdasarkan jumlah siswa dan kebutuhan khusus tertentu. Otonomi kepada sekolah diberikan untuk memanfaatkan bantuan, administrasi, dan pedagogik. Sekolah juga memiliki kewenangan untuk menetapkan tujuan jangka pendek dan jangka panjang sekolahnya, termasuk membuat keputusan tentang kurikulum, jadwal sekolah, pedagogik, dan lainnya. Transparansi dalam pengambilan keputusan dikembangkan, yang kemudian teryata dapat meningkatkan efisiensi. Pembelian barang langsung dilakukan oleh Dewan Sekolah, sehingga dapat dipilih barang yang lebih murah dan bermutu. Hanya urusan-urusan yang dianggap sangat penting yang masih berada di tangan pusat, seperti tawar-menawar dengan serikat pekerja, pola kurikulum, dan beberapa lainnya. Penetapan kepala sekolah dilaksanakan melalui pemilian oleh Dewan Sekolah dari tiga calon yang diajukan. Dengan cara ini, maka pemilihan kepala sekolah berangsur-angsur bergeser dari pertimbangan kedekatan atau politik, menjadi lebih didasari kemampuan teknis dan professional. Dilaporkan pula bahwa kinerja Dewan Sekolah beragam, tetapi umumnya menjurus ke independensi, meskipun sebagian didominasi oleh kepala sekolah.

\section{f. Kesadaran akan penderitaan di bawah rezim otoriter}

Sesudah 40 tahun Spanyol dikuasai oleh diktator militer Jenderal Franco, yang meninggal pada tahun 1795, gerakan rakyat yang dimotori oleh para mahasiswa menghasilkan konstitusi baru yang demokratis dan ditandatangani pada 1978. Otonomi politik diberikan pada 17 wilayah melalui pemilihan. Dengan otonomi tersebut, identifikasi terhadap masalah regional cepat teridentifikasi dan cepat pula ditangani. Masalah yang terjadi di daerah terpencil pun dapat cepat di identifikasi dan segera diatasi oleh masing-masing wilayah. Masing-masing wilayan mendapat block grant dari pusat. Pendidikan berkembang lebih pesat. Tetapi masalah dihadapi, yaitu kurang tersedia kepala sekolah yang cakap, karena gaji yang rendah tidak menarik orang-orang cakap melamar menjadi kepala sekolah. Peralihan dari pemerintah otoriter ke pemerintahan demokratis berlangsung mulus karena semua sadar betapa menderitanya rakyat di bawah pemerintahan otoriter dan selama perang saudara yang berlangsung sebelumnya. 


\section{g. Mengefisienkan desentralisasi}

Pada saat mulai melaksanakan desentralisasi, Selandia Baru mengurangi staf pendidikan di pusat dan menghapus pengelola pendidikan di wilayah. Tanggung jawab alokasi biaya, pengangkatan guru, dan pembuatan keputusan diserahkan langsung ke masing- masing sekolah. Sekolah kemudian dikelola oleh Dewan sekolah yang terdiri dari wakil orang tua, kepala sekolah, wakil guru, wakil siswa, dan wakil masyarakat. Pusat memberikan subsidi kepada sekolah berdasarkan jumlah siwa, dan sekolah didorong untuk mencari sumber dana lainnya bagi keperluan biaya rutin dan gaji guru. Untuk kelompok anak-anak yang tidak beruntung, seperti mereka yang tinggi di daerah terisolasi, biaya disediakan secara khusus oleh pemerintah pusat. Perubahan yang sangat signifikan adalah desentralisasi pendidikan di Negara tersebut mendorong terjadinya reformasi pedagogik.

\section{h. Memuluskan desentralisasi}

Pada tahap lanjut desentralisasi pendidikan di Meksiko (1988- 1993) berjalan mulus karena serikat pekerja dan para gubernur Negara bagian menyetujui kebijakan ini. Hal yang sama terjadi di Argentina pada tahun 1993 ketika desentralisasi sekolah menengah dilakukan. Adanya kesepakatan antara pemerintah daerah dan pusat membuat desentralisasi berjalan mulus. Sementara itu, setelah pemerintahan militer yang otoriter di Chile berganti dengan pemerintahan yang demokratis, status guru dihargai lagi, jaminan hari tua kembali diperoleh, hak berorganisasi didapat, dan hak untuk mengembangkan kreativitas diperoleh kembali. Antusiasme guru dalam bekerja pun meningkat. Dari pengalaman Chile diperoleh pelajaran bahwa desentralisasi dalam wujud otonomi kurikuler dan hak membuat keputusan pendidikan dapat meningkatkan mutu pendidikan. Untuk mendorong prakarsa guru, di Indonesia, pada 1993-1999 dikembangkan disemniasi penelitian tindakan (action research) kepada guru-guru SD di bawah pembinaan 89 LPTK yang tersebar diseluruh propinsi. Dengan didukung oleh sistem kredit promosi guru SD dan buku pedoman penelitian tindakan, diharapkan para guru SD dapat mengimplementasikan kurikulum dan meningkatkan kinerjanya. 


\section{i. Relevansi untuk Indonesia}

Dari contoh-contoh di atas dapat dikemukakan hal-hal relevan dengan Indonesia. Pertama, dalam rangka desentralisasi pendidikan, staf perlu dikurangi, kantor wilayah yang merupakan kepanjangan tangan pusat perlu dihapus, kantor pendidikan di tingkat kabupaten/kota lebih bertindak sebagai fasilitator, dan pengelolaan pendidikan diserahkan ke sekolah. Kedua, proporsi anggaran pendidikan yang selama ini $70 \%$ untuk pengelolaan di pusat/wilayah dan hanya $30 \%$ untuk sekolah perlu diubah menjadi $10 \%$ untuk pengelolaan dan $40 \%$ untuk sekolah, sedangkan 50\% lainnya untuk fungsi pemerataan bagi sekolah-sekolah yang belum memperoleh alokasi bantuan atau sbusidi. Ketiga, kurikulum nasional perlu lebih dirampingkan dan disajikan dalam suatu kerangka yang lebih jelas dengan memuat materi-materi yang dinilai paling esensial untuk dikuasai oleh para siswa. Sementara itu, kurikulum muatan lokal dijabarkan oleh sekolah. Keempat, fungsi pusat lebih mengarah pada penetapan kriteria/standar untuk mempertahankan mutu dan relevansi pendidikan serta melakukan pemantauan guna memastikan bahwa standar tersebut dilaksanakn oleh daerah atau sekolah.

\section{Kebijakan Kurikuler}

Kebijakan kurikuler pendidikan di berbagai Negara sangat beragam. Di banyak Negara, Menteri Pendidikan menetapkan kurikulum untuk semua sekolah, dikenal dengan kurikulum nasional. Tetapi di Negara lainnya, daerah mengembangkan kurikulum sendiri. Misalnya, di Amerika Serikat, kurikulum pendidikan dan bahkan sistem pendidikan beragam antarnegara bagian. Negara bagian Hawaii menggunakan satu sistem sekolah, sedangkan Negara bagian New York menggunakan satu sistem ujian. Menurut konstitusi AS, otoritas pendidikan didelegasikan kepada daerah (local public school system).

National Defence Act (NDEA) AS memberi peluang kepada penyelenggara pendidikan untuk mengembangkan kurikulum yang lebih baik untuk sains, matematika, dan bahasa asing, sekaligus melatih gurunya, sementara pemerintah federal menyediakan dananya. Sistem pendidikan lokal dapat memperoleh dana federal untuk mengembangkan kurikulum pendidikan kejuruan dan pendidikan untuk anak-anak berkelainan. Namun, meskipun setiap sekolah bebas untuk 
mengenmbangkan kurikulumnya sendiri, hampir semua Negara bagian menetapkan sejumlah pelajaran yang wajib diberikan di sekolah, misalnya biologi, sejarah AS, dan dampak penggunaan alkohol. Hal yang sama berlaku di jenjang perguruan tinggi, khususnya perguruan tinggi negeri. Mahasiswa dituntut untuk menempuh mata kuliah tertentu yang ditetapkan oleh Negara bagian. Atas nama kepentingan nasional, pada periode ketika pemerintah federal ikut menentukan kurikulum sekolah. Pada tahun 1960, Kongres AS secara resmi mengintervensi kurikulum sekolah dengan mengembangkan kurikulum nasional, dan Kantor Pendidikan Ferderal dikembangkan menjadi Departemen Pendidikan. Di antara alasannya ialah tidak mudah bagi Negaranegara bagian untuk mengambil keputusan tentang sesuatu yang bersifat nasional. Oleh karena itu, pemerintahan federal itulah yang harus menanganinya. Lembagalembaga nonpemerintah juga ikut berperan dalam penetapan kebijakan tentang pengembangan kurikulum, seperti National Council of Teachres in English, National Education Association, dan Accrediting Associations lainnya. Begitu juga perguruan tinggi mempunyai pengaruh terhadap sekolah menengah melalui penetapan persyaratan masuk ke perguruan tinggi.

Negara yang sangat demokratis seperti AS sekalipun, ada kecenderungan (pemerintah) untuk mengembangkan kurikulum nasional, terlepas dari seberapa porsinya dibandingkan dengan kurikulum lokal. Diketahui pula bahwa dalam sistem pendidikan yang sangat desentralistik sekalipun, selalu ada komponen kurikulum nasional dan muatan lokal. Hal seperti ini juga terjadi di Negara-negara lainnya, seperti Jepang, Swedia, Prancis, dan Inggris. Dari telaah di atas, dapat disimpulkan bahwa sesungguhnya kebijakan tentang komponen nasional dan lokal dari kurikulum pendidikan Indonesia tidak menyimpang dari kelaziman, karena itu perlu dipertahanakn. Masalahnya adalah berapa banyak porsi untuk masing-masing komponen tersebut. Perlu juga ditelaah kembali, apakah kurikulum nasional itu benarbenar mengandung kemampuan generik.

\section{Biaya Pendidikan dari Keluarga dan Masyarakat}

Telah diketahui bahwa biaya pendidikan setiap siswa/mahasiswa untuk penyelenggaraan berasal dari berbagai sumber. Di Amerika Serikat, satuan biaya per 
mahasiswa di Universitas Negeri $18 \%$ berasal dari SPP (tuition fee) mahasiswa, $42 \%$ dari subsidi pemerintah, dan $40 \%$ lainnya dari donasi dan sumber usaha yayasannya. Komposisi ini berbeda dengan di Universitas swasta dimana satuan biaya per mahasiswa sebanyak $48 \%$ berasal dari tuition fee mahasiswa, $18 \%$ dari subsidi pemerintah, dan $34 \%$ sisanya dari donasi dan sumber usaha lain. Di Indonesia, anggaran sekolah negeri sebagian besar atau bahkan hampir seluruhnya berasal dari pemerintah, sedangkan anggaran sekolah swasta hampir seluruhnya dibayar oleh keluarga yang dikelola oleh yayasan yang bersangkutan. Keadaan ini kemudian memunculkan isu keadilan (equity, fairness) dalam memperoleh subsidi pemerintah di satu pihak, dan tanggung jawab keluarga dan masyarakat dalam membiayai pendidikan. Di antara pertanyaan yang muncul ialah: siapa berhak disubsidi dan mengapa?

Selama ini, sumber biaya pendidkan yang berasal dari masyarakat merupakan bagian terkecil dari keseluruhan struktur sumber-sumber biaya pendidikan di Indonesia. Pada tahun anggaran 1997/1998, 11,78\% dana penyelenggaraan perguruan tinggi negeri di Indonesia berasal dari mahasiswa dan orang tua, 10,59\% berasal dari berbagai program kerja sama kolaboratif dan sumber lain yang diperoleh perguruan tinggi, sedangkan sebagian besar lainnya $(77,63 \%)$ berasal dari pemerimtah (Ditjen Dikti, 1999). Jadi, hanya sekitar seperlima biaya pendidikan tinggi negeri yang berasal dari masyarakat. Tentu saja kondisi ini berlawanan dengan perguruan tinggi swasta. Meskipun sekitar seperlima dosennya berstatus pegawai negeri yang diperbantukan oleh pemerintah, sebagian besar dana penyelenggaraan perguruan tinggi swasta berasal dari mahasiswa.

Sesuai dengan PP No.61/1999, kebijakan yang dikembangkan untuk masa mendatang mengarah pada otonomi pengelolaan perguruan tinggi yang juga berimplikasi pada akan semakin membesarnya proporsi sumber biaya pendidikan dari masyarakat yang dihimpun oleh perguruan tinggi yang bersangkutan. Kondisi ini mestinya juga diharapkan akan terjadi pada tingkat pendidikan dasar dan menengah. Sumber biaya pendidikan dari masyarakat akan menjadi komponen yang sangat menentukan penyelenggaraan

1. Menjadikan pendidikan sebagai pilar uatama pembangunan bangsa. 
2. Pendidikan harus berfungsi sebagai transformasi kebudayaan atau pusat pembudayaan kemampuan, nilai dan sikap dalam membentuk masyarakat modern.

3. Untuk mengembangkan pendidikan yang berfungsi sebagai pusat pembudayaan, diperlukan guru/tenaga pendidik yang pendidikan, bukan saja di lembaga pendidikan swasta, melainkan juga di lembaga pendidikan negeri. Kemampuan ekonomi masyarakat yang menguat dan kesadaran akan pentingnya pendidikan yang semakin meningkat akan sangat menentukan keberhasilan kebijakan dasar ini.

\section{KESIMPULAN}

Melihat dari pandangan politik Bangsa Indonesia, khususnya para pendiri bangsa menunjukkan adanya keinginan yang kuat untuk membangun peradaban Bangsa Indonesia menjadi lebih maju dan bermartabat, cita-cita tersebut secara konseptual tertuang dalam UUD 1945 yang kemudian diterjemahkan secara operasional kedalam UU Sistem Pendidikan Nasional sebagai acuan dalam pelaksanaan pendidikan. Setelah masa reformasi terdapat keinginan yang kuat supaya terjadi pemerataan pembangunan, dan ditetapkanlah Otonomi Daerah sebagai solusinya. Berlakunya ketentuan otonomi daerah mempunyai implikasi terhadap pelaksanaan pendidikan sebagai upaya mencerdaskan kehidupan bangsa dengan berbagai macam konsekuensi-konsekuensi yang harus ditanggung. Berlandaskan pada landasan politik melalui ketentuan UU Sisdiknas dan Otonomi Daerah dapat ditarik kesimpulan tentang beberapa orientasi pendidikan sebagai implikasinya:

1. Proses belajar diarahkan pada penguasaan semua aspek kompetensi baik kognitif, psikomotor, maupun afektif.

2. Mengembnagkan sistem evaluasi yang komprehensif, terus-menerus dan objektif, yang dapat merangsang berkembangnya potensi peserta didik secara maksimal.

3. Tersedianya infrastruktur yang memadahi.

4. Pemerataan pendidikan yang berkualitas dan bermutu. Professional 


\section{DAFTAR PUSTAKA}

Abu ahmadi \& Nur Uhbiyati, Ilmu Pendidikan, ( Jakarta, PT Rineke Cipta, 2003)

Dr. Fasli Jalal \& Prof. Dr. Dedi Supriadi, Reformasi Pendidikan dalam Konteks Otoniomi Daerah, (Yogjakarta, Adicipta Karya Nusa, 2001)

Hasbullah, Dasar-dasar Ilmu Pendidikan, ( Jakarta, PT Raja Grafindo Persada, 2009)

Soedijarto, Landasan dan Arah Pendidikan Nasional Kita, ( Jakarta: Kompas, 2008).

Soedijarto, Pendidikan Nasional sebagai wahana mencerdaskan kehidupan bangsa dan membangun peradaban Negara bangsa, (CINAPS, 2000),

Surakhmad, Winarno. Prof. Dr. dkk, Menguarai Benang Kusut Pendidikan, (Jakarta: Pustaka Pelajar, 2003).

Tilaar, A. R. Prof. Dr. H. M.Sc. Ed, Paradigma Baru Pendidikan Nasional, (Jakarta: PT. Rinek Cipta, 2004).

Undang-undang Dasar Negara Republik Indonesia Tahun 1945. Undang-undang Republik Indonesia Nomor 20 Tahun 2003 Tentang

Sistem Pendidikan Nasional, (Jakarta, Depdiknas, 2003). 